$300 \mathrm{mg}$. or less. The activity lay within the normal range and did not correlate with cholesterol levels.

Atromid-S (clofibrate) lowered the serum cholesterol significantly in 15 of the patients compared with 15 controls.

Fibrinolytic activity did not change significantly in either treated or control groups.

These results are in striking contrast with those of a previous trial involving patients with hypercholesterolaemia.

\section{REFERENCES}

Fearnley, G. R., Chakrabarti, R., and Avis, P. R. D. (1963). Brit. med. F., 1, 921 .

Goldrick, R. B. (1961). Aust. Ann. Med., 10, 20.

Howard, R. P., Alaupovic, P., Brusco, O. J., and Furman, R. H. (1963). 7. Atheroscler. Res., 3, 482 .

Merskey, C., Gordon, H., Lackner, H., Schrire, V., Kaplan, B. J., Sougin-Mibashan, R., Nossel, H. L., and Moodie, A. (1960). Brit. med. 7., $1,219$.

Oliver, M. F. (1963). 7. Atheroscler. Res., 3, 427.

Srivastava, S. C., Smith, M. J., and Dewar, H. A. (1963). Ibid., 3, 640.

\title{
Induction of Labour by Intra-amniotic Hypertonic Saline
}

\author{
DAVID R. MILLAR,* M.B., F.R.C.S.ED., M.R.C.o.G. ; LEONARD P. HARVEY, † M.B., M.R.C.O.G.
}

Brit. med. F., 1966, 1, 327-330

Throughout obstetrics there is a conflict between conservative management and operative intervention. Nowhere is the problem of induction of labour more controversial than when the foetus is dead or deformed. The efficacy of the various methods of induction must be balanced against the inevitability of labour. Conservative management may be complicated by mental distress in the mother awaiting labour (Corbett, 1958), hypofibrinogenaemia with a dead baby (Barry et al., 1955 ; Quinn and Harper, 1958), or dystocia at term with a large malformed foetus. These dangers may tempt the obstetrician to intervene.

On the other hand, there are undoubted maternal hazards in the conventional methods of induction. Amniotomy may introduce infection into a dead pregnancy, while rapid drainage of massive hydramnios (for example, in anencephaly) may provoke placental separation (Cunningham, 1965). Missed abortion in the first three months may be evacuated surgically, but here, too, there is a risk of haemorrhage. Various forms of medical induction with oestrogens, quinine, and oxytocin injections have been found unreliable (Martin and Menzies, 1955).

A failed induction in this type of case merely serves to increase maternal distress and frustration, so that the method used must be both safe and reliable.

Similarly in the rare cases when therapeutic termination of pregnancy is indicated it is equally essential that an induction be effective and without significant risk to a mother who may be too ill to withstand hysterotomy. Simple dilatation and curettage is practicable only before the twelfth week, and often the decision about termination has not been made as early as this. Thus there is a need for a reliable method of inducing abortion in the second trimester.

\section{New Methods of Induction}

\section{Intra-amniotic Hypertonic Saline}

Burke (1935) reported that Uroselectan B injected for amniography often induced labour, and it was used for this purpose by Playfair (1941). Hypertonic glucose was also used at this time, but the method was abandoned for normal cases because of a high incidence of intrauterine death.

Aburel (1934) first described the instillation of " a serum containing $33 \%$ sodium chloride" into the amniotic sac as a

\footnotetext{
* Registrar, Birmingham Maternity Hospital. At present, Lecturer, Department of Obstetrics and Gynaecology, University of Liverpool t Registrar, Birmingham Maternity Hospital.
}

safe and reliable method of terminating early pregnancy. The increasing demand for legalized abortion in Scandinavia has resulted in renewed interest in the method (Svane, 1960 ; Wagner et al., 1962). Such cases have been used to study the physiology of uterine action (Bengtsson and Csapo, 1962 ; Wiqvist and Eriksson, 1964). Fifty per cent. glucose has also been used successfully (Brosset, 1958 ; Wood et al., 1962), but there have been two reports of maternal deaths due to anaerobic infection following this technique (Briggs, 1964 ; MacDonald et al., 1965). Glucose favours the growth of saccharolytic organisms, and therefore saline might be safer. On the other hand, there is a theoretical risk of overloading the circulation with saline in pre-eclampsia and cardiac disease.

The method is unacceptable as a routine means of induction because the hypertonic solution often kills the baby, but it is applicable not only for therapeutic abortion but also in cases of gross foetal abnormality incompatible with life and when the baby is already dead (Csapo et al., 1963b).

For therapeutic abortion the intra-amniotic injection is best performed by the abdominal route after the sixteenth week. This delay allows the obstetrician more time to consider fully the indications for the operation.

In cases of intrauterine death amniocentesis can be carried out with complete sterility, avoiding the risk of infection which accompanies conventional amniotomy. Should induction fail, therefore, one is not committed to an operative delivery.

\section{High-dosage Oxytocin Infusion}

This is effective when the baby is dead (Loudon, 1959; Liggins, 1962), but rarely cardiovascular and antidiuretic complications do occur (Reinberger and Mackey, 1958; Mayes and Shearman, 1956 ; Abdul-Karim and Assali, 1961).

The method is completely unsuccessful in inducing therapeutic abortion and relatively ineffective in viable pregnancies with intact membranes.

Surgical induction by amniotomy, as a prelude to oxytocin, greatly increases the efficiency and success of the method. However, on those occasions when such inductions fail with an abnormal baby, the hazards of intrauterine infection increase the longer the awkward decision to undertake caesarean section is postponed.

Though disproportion is seldom present in the group of premature inductions under discussion, rupture of the uterus 
has even been reported after a high-dosage oxytocin drip for a missed abortion of 20 weeks' maturity (Dunlop, 1964).

\section{Recent Series}

The present scries of 32 consecutive saline inductions, including 5 therapeutic abortions, 9 cases with retention of a dead foetus, and 18 grossly abnormal babies, was undertaken by us at three hospitals in the Birmingham Region.

\section{Method}

As a preliminary precaution, when the baby was dead, maternal blood was examined for defects in the formation and stability of clot, but no cases of hypofibrinogenaemia were found.

The patient was given a sedative and emptied her bladder immediately before the procedure. An $x$-ray film had usually been taken to confirm foetal death or abnormality. After careful palpation of the abdomen and study of the $x$-ray film to determine the foetal lie, the skin was prepared, with full sterile precautions, in a surgical theatre. A 17-gauge spinalanaesthetic needle, with stylet, was inserted into the amniotic sac under local anaesthesia, entering below the umbilicus and slightly to the side opposite the foetal trunk. If possible, 200 $\mathrm{ml}$. of liquor amnii was withdrawn and replaced with $200 \mathrm{ml}$. of 20 -normal $(18 \%)$ saline. In the missed abortions only small volumes of liquor were obtained. Large volumes were of ten removed in cases of foetal abnormality with hydramnios, in an attempt to prevent overdilution of the saline. The doses of saline injected ranged from 60 to $250 \mathrm{ml}$. The needle was cleared with a few millilitres of normal saline before withdrawal, and more recently we have been introducing $500 \mathrm{mg}$. of oxytetracycline as a prophylactic measure (Harvey, 1964). The patient remained under close observation, especially for the first hour.

\section{Group I. Therapeutic Abortions (see Table I)}

In Cases 3, 4, and $5200 \mathrm{ml}$. of liquor was replaced with saline and an efficient complete abortion was induced within three days.

\begin{tabular}{|c|c|c|c|c|c|c|}
\hline $\begin{array}{l}\text { Case } \\
\text { No. }\end{array}$ & $\begin{array}{l}\text { Maturity } \\
\text { at Induc- } \\
\text { tion } \\
\text { (Weeks) }\end{array}$ & $\begin{array}{c}\text { Vol. } \\
\text { Liquor } \\
\text { Aspirated } \\
\text { (ml.) }\end{array}$ & $\begin{array}{l}\text { Vol. } \\
\text { Saline } \\
\text { Injected } \\
\text { (ml.) }\end{array}$ & $\begin{array}{l}\text { I.D.I. } \\
\text { (Hours) }\end{array}$ & $\begin{array}{l}\text { Labour } \\
\text { (Hours) }\end{array}$ & Notes \\
\hline 1 & 14 & 100 & 100 & 84 & 8 & $\begin{array}{l}\text { Multiple sclerosis (oxy- } \\
\text { tocin drip } 200 \text { mU/ } \\
\text { min for } 8 \text { hours) }\end{array}$ \\
\hline $\begin{array}{l}2 \\
3\end{array}$ & $\begin{array}{l}18 \\
16\end{array}$ & $\begin{array}{l}100 \\
200\end{array}$ & $\begin{array}{l}100 \\
200\end{array}$ & $\begin{array}{l}57 \\
40\end{array}$ & $\begin{array}{r}29 \\
6\end{array}$ & $\begin{array}{l}\text { Epilepsy: rape aged } 18 \\
\text { Severe Rh-isoimmuniza- } \\
\text { tion }\end{array}$ \\
\hline 4 & 20 & 200 & 200 & 6 & 4 & Severe bilateral bron- \\
\hline 5 & 18 & 200 & $200+T$ & 57 & 13 & Rape aged 13 \\
\hline
\end{tabular}

When only $100 \mathrm{ml}$. was replaced, however, the result was not so satisfactory. One patient (Case 2) had a long inefficient labour prior to her abortion, and another (Case 1) lost some of her hypertonic liquor following spontaneous rupture of the membranes a few hours after the induction. The saline must have had some destructive effect on the pregnancy, however, for it was rapidly aborted with an oxytocin drip on the fourth day. Even the high dose of oxytocin used-200 milliunits $(\mathrm{mU}) / \mathrm{min}$.--would have had no effect on an intact living 14week pregnancy. In no case was subsequent curettage necessary.
It is concluded that with a live pregnancy $200 \mathrm{ml}$. of 20 normal saline is a reliable dose to induce abortion.

\section{Group II. Intrauterine Deaths (see Table II)}

This series shows that in the case of intrauterine death a smaller dose of saline is effective. In the eight cases where the dose exceeded $100 \mathrm{ml}$. the average induction-delivery interval was only 18.5 hours.

TABLE II.-Nine Intrauterine Deaths: Inductions of Labour by

\begin{tabular}{|c|c|c|c|c|c|c|c|}
\hline & & & tra-amni & c Hype & nic $S$ & line & \\
\hline $\begin{array}{l}\text { Case } \\
\text { No. }\end{array}$ & $\begin{array}{l}\text { Maturity } \\
\text { at } \\
\text { Induc- } \\
\text { tion } \\
\text { (Weeks) }\end{array}$ & $\begin{array}{l}\text { Estimated } \\
\text { Duration } \\
\text { of } \\
\text { Foetal } \\
\text { Death } \\
\text { (Weeks) }\end{array}$ & $\begin{array}{c}\text { Vol. } \\
\text { Liquor } \\
\text { Aspirated } \\
\text { (ml.) }\end{array}$ & $\begin{array}{l}\text { Vol. } \\
\text { Saline } \\
\text { Injected } \\
\text { (ml.) }\end{array}$ & $\begin{array}{l}\text { I.D.I. } \\
\text { (Hours) }\end{array}$ & $\begin{array}{l}\text { Labour } \\
\text { (Hours) }\end{array}$ & Notes \\
\hline $\begin{array}{l}6 \\
7\end{array}$ & $\begin{array}{l}34 \\
35\end{array}$ & ? 15 & $\begin{array}{l}2 \\
2\end{array}$ & $\begin{array}{r}60 \\
150\end{array}$ & $\begin{array}{l}56 \\
17\end{array}$ & $\begin{array}{l}2 \\
4\end{array}$ & $\begin{array}{c}\text { Missed abortion } \\
\text { (f̈elt faint) }\end{array}$ \\
\hline 8 & 33 & 4 & 40 & 150 & 19 & 8 & $\begin{array}{l}\text { I.U.D. ? cause. } \\
\text { Injection }\end{array}$ \\
\hline 9 & 33 & 2 & 10 & 180 & 21 & 9 & $\begin{array}{l}\text { Failed oxytocin } \\
\text { drip }\end{array}$ \\
\hline $\begin{array}{l}10 \\
11 \\
12 \\
13 \\
14\end{array}$ & $\begin{array}{l}29 \\
35 \\
31 \\
32 \\
34\end{array}$ & $\begin{array}{l}2 \\
1 \\
7 \\
1 \\
1\end{array}$ & $\begin{array}{r}80 \\
5 \\
10 \\
10 \\
5\end{array}$ & $\begin{array}{l}200 \\
200 \\
100+\mathrm{T} \\
100+\mathrm{T} \\
100+\mathrm{T}\end{array}$ & $\begin{array}{r}21 \\
39 \\
11 \\
7 \\
12\end{array}$ & $\begin{array}{l}5 \\
9 \\
4 \\
2 \\
7\end{array}$ & $\begin{array}{l}\text { Rhesus I.U.D. } \\
\text { I.U.D. ? cause } \\
\text { Missed abortion } \\
\text { Severe P.E.T. } \\
\text { Gravida-3. No } \\
\text { living children }\end{array}$ \\
\hline
\end{tabular}

I.D.I. $=$ Induction-delivery interval. $T=500 \mathrm{mg}$. oxytetracycline. I.U.D. $=$ Intrauterine death. P.E.T. $=$ Pre-eclamptic toxaemia.

An inadequate dose was the probable cause of delay in Case 6. Owing to the absence of liquor there was some doubt whether the amniotic sac had been entered in this missed abortion.

In none of this series was more than $80 \mathrm{ml}$. of liquor obtained, and some technical difficulty in locating the amniotic sac was common. In Case 8 the initial saline injection caused some pain and was probably partly into the myometrium. One patient (Case 7) felt faint and sweated profusely for a few minutes after the injection, but there was no other complication. There was no obvious relation between the induction-delivery interval, and the time or duration of foetal death and labour was invariably brief and efficient (averaging just over five hours).

Case 9 had had an oxytocin infusion a few days previously and was the only failure in a parallel series of 12 cases treated with high-dosage Syntocinon. In another eight of these 12 cases the first infusion was successful, the induction-delivery interval averaging eight and a half hours and the dose up to 100 units of oxytocin per pint. The remaining three patients were delivered only after a repeat infusion on the second day. Labour, when established, was also rapid in this oxytocin group and there was no case of excessive loss of blood or retained placenta.

The conclusion is that intra-amniotic saline and highdosage oxytocin are comparable methods of induction when the foetus is dead.

The saline injection, though it may prove difficult to introduce, seems to be more reliable.

\section{Group III. Foetal Abnormality (See Table III)}

That hydramnios had a profound influence on the results of induction in this group is demonstrated by reference to columns 3 and 4 of Table III. The long induction-delivery intervals in Cases 16, 24, and 25 were manifestly due to overdilution of the saline by residual liquor. In two of these, oxytocin stimulation had to be added on the third or fourth day, but though the labies were still alive at this time the uterus showed considerable sensitivity (especially in Case 24, where only $1.5 \mathrm{mU} / \mathrm{min}$. was required). When the membranes 
eventually ruptured in these three cases, over 3 litres of liquor remained, and in Case 25 amniotomy, even during labour, provoked retroplacental bleeding.

With moderate hydramnios 1 to 2 litres of liquor seemed to be the optimum volume to remove. The aspiration of larger volumes was required in gross hydramnios, and no major abruption of the placenta was caused. Despite the added stimulus to labour of a small concealed haemorrhage in Case 29 , the withdrawal of as much as 6 litres of liquor seemed to delay the onset of labour. The rapid results despite hydramnios in Cases 20 and 26 were explained by the birth of macerated babies.

The average induction-delivery interval was 34.5 hours, and over 48 hours in six cases. In four of these six the delay was attributable to hydramnios as described above. In the other two cases oligo-hydramnios led to technical difficulties. Baby 31 had a sloughing area on the thorax indicating that most of the saline had been deposited subcutaneously. Failure to find the amniotic cavity on amniocentesis in Case 32 was overcome by injecting the saline up a Drew Smythe catheter after hind-water puncture.

Both these cases were given oxytocin in modest dosagethe former because of the inadequate injection of saline, and the latter, on the second day, because of concern about potential intrauterine infection.

The hazard of infection was also present in two cases which developed pyrexia on the third day (Cases 16 and 24). In neither case were pathogens cultured. Nevertheless, it was after these cases that we began to instil oxytetracycline into the amniotic cavity at induction.

As in groups I and II, the duration of labour was remarkably constant, averaging five and a half hours.

Two patients felt faint at induction, but both had gross hydramnios and the supine hypotensive syndrome may well have been responsible.

Two manual removals of partially adherent placentae were required, but we do not believe that these were related to the methods of induction. There were no other complications.

Sixteen of the 18 babies were alive at induction, three surviving birth for a few minutes. The usual effect of the saline was to provoke excess foetal movements initially, but the foetal heart was seldom heard after a few hours, especially in the most successful cases.

It should be noted that two patients in this series (Cases 16 and 20 ) had had a previous failed medical induction with oxytocin.

\section{Discussion}

There is no doubt from this and other series that saline inductions are effective.

Their mode of action, however, is still uncertain. Csapo's theory that the injected solution interferes with the hormonal function of the placenta and removes a "progesterone block" is an attractive one, and based on careful analytical experiments on pregnant rabbits (Csapo, 1955 ; 1961a, 1961b, 1961c ; Csapo and Lloyd Jacob, 1962). It is supported by the finding that large doses of parenteral progesterone will delay the onset of therapeutic abortion after intra-amniotic saline (Bengtsson, 1961a). Bengtsson (1962) has also shown, in missed abortions, that the sensitivity of the uterus to oxytocin is related to pregnanediol excretion. If placental progesterone secretion is maintained, a saline induction is more satisfactory than an oxytocin drip. In this series we have confirmed increased uterine sensitivity to oxytocin after intra-amniotic hypertonic saline.

It has never been possible, however, to demonstrate convincingly any fall in pregnanediol excretion (Scott Russell, 1961) or in systemic blood (Zander, 1961) or uterine vein (Short et al., 1965) progesterone levels before labour. Nor can injections of progesterone postpone normal labour.

Csapo (1961d, 1963) believes that it is the local concentration of progesterone in the myometrium at the placental site which is important, and describes an endocrine as well as a functional asymmetry of the uterus. There is some evidence that intra-amniotic (Hendricks et al., 1961) or intramyometrial (Bengtsson, 1961b) progesterone will delay labour.

The histological changes in the placenta are not gross after saline inductions, so the chemical or physical effects of the injected solution must be more subtle. Saline can have no specific biochemical effect, as glucose is equally efficient. Nor, for the same reason, can the supposition of the release of oxytocin due to an increased osmolarity of the maternal plasma be of any major importance.

It has also been suggested that simple uterine distension due to absorption of water into the hypertonic liquor might induce labour. However, little increase in intra-amniotic tension is demonstrable in the latent interval before labour starts (Bengtsson and Csapo, 1962; Wiqvist and Eriksson, 1964), and, indeed, in many of the present cases the liquor volume was drastically reduced.

It has been noted that labour was characteristically short (about six hours) after saline inductions, irrespective of the state of the cervix, the parity of the mother, or the maturity

TABLE III.-18 Cases of Foetal Abnormality: Induction of Labour by Intra-amniotic Hypertonic Saline (Grouped by Estimate of Liquor Volume)

\begin{tabular}{|c|c|c|c|c|c|c|c|c|c|c|}
\hline $\begin{array}{l}\text { Case } \\
\text { No. }\end{array}$ & $\begin{array}{c}\text { Maturity } \\
\text { at } \\
\text { Induction } \\
\text { (Weeks) }\end{array}$ & Hydramnios & $\begin{array}{l}\text { Vol. } \\
\text { Liquor } \\
\text { Aspirated } \\
\text { (ml.) }\end{array}$ & $\begin{array}{c}\text { Vol. } \\
\text { Saline } \\
\text { Injected } \\
\text { (ml.) }\end{array}$ & $\begin{array}{c}\text { Oxytocin } \\
\text { Used } \\
\text { (mU/min./ } \\
\text { hours) }\end{array}$ & $\begin{array}{l}\text { I.D.I. } \\
\text { (Hours) }\end{array}$ & $\begin{array}{l}\text { Labour } \\
\text { (Hours) }\end{array}$ & $\begin{array}{c}\text { Foetal } \\
\text { Abnormality }\end{array}$ & Result & Notes \\
\hline $\begin{array}{l}15 \\
16\end{array}$ & $\begin{array}{l}39 \\
38\end{array}$ & $\begin{array}{l}\text { Nil } \\
\text { Moderate }\end{array}$ & $\begin{array}{l}100 \\
200\end{array}$ & $\begin{array}{l}200 \\
200\end{array}$ & - & $\begin{array}{l}12 \\
59\end{array}$ & $\begin{array}{l}4 \\
7\end{array}$ & $\begin{array}{c}\text { Anencephalic } \\
\text { „ }\end{array}$ & $\begin{array}{l}\text { N.N.D. } \\
\text { S.B. }\end{array}$ & $\begin{array}{l}\text { Transient pyrexia. Previous I.M. oxytocin. } \\
\text { A.R.M. } 3 \text { l. liquor. }\end{array}$ \\
\hline $\begin{array}{l}17 \\
18 \\
19 \\
20\end{array}$ & $\begin{array}{l}34 \\
34 \\
38 \\
35\end{array}$ & $\begin{array}{l}\text { ", } \\
\text { ", }\end{array}$ & $\begin{array}{r}500 \\
700 \\
1,000 \\
1,200\end{array}$ & $\begin{array}{l}200+\mathrm{T} \\
200 \\
200 \\
200\end{array}$ & E & $\begin{array}{l}10 \\
11 \\
19 \\
10\end{array}$ & $\begin{array}{l}6 \\
8 \\
3 \\
3\end{array}$ & $\begin{array}{l}\text { ", } \\
\text { ", }\end{array}$ & $\begin{array}{l}\text { S.B. } \\
\text { S.B. } \\
\text { S.B. } \\
\text { Early } \\
\text { maceration }\end{array}$ & Previous failed oxytocic drip \\
\hline $\begin{array}{l}21 \\
22 \\
23\end{array}$ & $\begin{array}{l}32 \\
30 \\
36\end{array}$ & ”, & $\begin{array}{l}1,300 \\
1,600 \\
1,800\end{array}$ & $\begin{array}{l}200 \\
150 \\
250\end{array}$ & $\overline{-}$ & $\begin{array}{l}30 \\
14 \\
14\end{array}$ & $\begin{array}{l}9 \\
6 \\
3\end{array}$ & ", & $\begin{array}{l}\text { maceration } \\
\text { S.B. } \\
\text { S.B. } \\
\text { S.B. }\end{array}$ & $\begin{array}{l}\text { Retained placenta } \\
\text { Revic drip }\end{array}$ \\
\hline $\begin{array}{l}24 \\
25\end{array}$ & $\begin{array}{l}30 \\
38\end{array}$ & $\begin{array}{c}\text { Gross } \\
, y\end{array}$ & $\begin{array}{r}300 \\
1,000\end{array}$ & $\begin{array}{l}200 \\
200+T\end{array}$ & $\begin{array}{l}1 \cdot 5 / 8 \\
10 / 12\end{array}$ & $\begin{array}{l}72 \\
98\end{array}$ & $\begin{array}{l}6 \\
6\end{array}$ & $\begin{array}{c}\text { Anencephalic } \\
,\end{array}$ & $\begin{array}{l}\text { S.B. } \\
\text { S.B. }\end{array}$ & $\begin{array}{l}\text { Pyrexia } 101^{\circ} \text { F. }\left(38.3^{\circ} \text { C.). A.R.M. } 4.5 \text { l. liquor }\right. \\
\text { After A.R.M. } 31 \text {. liquor. Small A.P.H.: } \\
\text { oxytocin discontinued }\end{array}$ \\
\hline 26 & 32 & $"$ & 2,000 & 200 & - & 9 & 4 & $\begin{array}{l}\text { Non-rhesus } \\
\text { hydrops }\end{array}$ & Macerated & \\
\hline $\begin{array}{l}27 \\
28 \\
29\end{array}$ & $\begin{array}{l}32 \\
31 \\
34\end{array}$ & ", & $\begin{array}{l}2,700 \\
3,500 \\
6,000\end{array}$ & $\begin{array}{l}150 \\
200+\mathrm{T} \\
250\end{array}$ & $\bar{E}$ & $\begin{array}{l}34 \\
18 \\
52\end{array}$ & $\begin{array}{l}8 \\
4 \\
2\end{array}$ & $\begin{array}{l}\text { Anencephalic } \\
\text { Iniencephalic } \\
\text { Ancncephalic }\end{array}$ & $\begin{array}{l}\text { S.B. } \\
\text { N.N.D. } \\
\text { S.B. }\end{array}$ & $\begin{array}{l}\text { Retained placenta } \\
\text { Small concealed A.P.H. }\end{array}$ \\
\hline 30 & 36 & Slight & 750 & 250 & - & 17 & 7 & Microcephaly, & $N N$ & \\
\hline $\begin{array}{l}31 \\
32\end{array}$ & $\begin{array}{l}38 \\
34\end{array}$ & $\begin{array}{l}\text { Oligo- } \\
\text { Oligo- }\end{array}$ & $\begin{array}{l}15 \\
15\end{array}$ & $\begin{array}{l}150+T \\
150+T\end{array}$ & $\begin{array}{l}3 / 18 \\
10 / 9\end{array}$ & $\begin{array}{l}93 \\
50\end{array}$ & $\begin{array}{l}6 \\
7\end{array}$ & $\begin{array}{l}\text { Anencephaly } \\
\text { Gross spina } \\
\text { bifida }\end{array}$ & $\begin{array}{l}\text { S.B. } \\
\text { S.B. }\end{array}$ & $\begin{array}{l}\text { Injection partly into baby } \\
\text { Injection by Drew Smythe catheter }\end{array}$ \\
\hline
\end{tabular}

I.D.I. $=$ Induction-delivery interval. $T=500 \mathrm{mg}$. oxytetracycline. S.B. $=$ Fresh stillbirth. N.N.D. $=$ Neonatal death. A.R.M. $=$ Artificial rupture of membrane (in labour). A.P.H. $=$ Antepartum haemorrhage. 
of the pregnancy. It would appear that when the progesterone "brake" is completely released the myometrium functions with maximum efficiency.

We recognize three groups of cases in which saline inductions are indicated, and the techniques involved may well vary in each group.

For therapeutic abortion the volume of liquor removed and the dose of saline replaced have been fairly well standardized in large series of cases (Wagner et al., 1962). We confirm that $200 \mathrm{ml}$. is a satisfactory volume of liquor to replace with 20 normal saline.

In the case of missed abortions (and long-retained dead foetuses) less saline is required, as the hormonal activity of the placenta may be only partly retained. Technical difficulty may be experienced owing to lack of liquor, and injection into the dead foetus achieves nothing. Hypertonic saline in the uterine muscle causes severe pain and may lead to vasomotor effects due to its rapid absorption into the systemic circulation. Despite these problems we still had no failed inductions in this group, and the method provides a reliable alternative to the high-dosage oxytocin drip.

The third type of case-the abnormal foetus-perhaps presents the most interesting problem, since hydramnios is often present. If large volumes of liquor are removed to prevent overdilution of the saline there is a significant risk of abruptio placentae. To prevent this it has been suggested that some form of uterine stimulant-oxytocin 1-2 units or dihydroergotamine $0.25 \mathrm{mg}$. intramuscularly (S. Davidsonpersonal communication)_might be given 10 to 15 minutes prior to induction.

The influence of the amniocentesis on the inductiondelivery interval is complicated. Whereas amniotomy per vaginam combined with cervical stimulation near term often induces labour, an abdominal liquor tap does not.

In hydramnios, reduction in liquor volume allows the uterus to contract till the length/tension ratio is optimal for activity, but reduction below this length may encourage inertia (Csapo et al., 1963a). There is thus an ideal amount of liquor to remove for mechanical efficiency in each case, and the problem then is to achieve an optimum concentration of saline in this liquor, allowing for subsequent fluid shift across the amnion.

Such problems can be solved only by studying large series of cases, with standardized dosage schedules, intra-amniotic pressure recordings, and measurements of liquor volume and the dilution of injected saline. Knowledge so gained, combined with a reliable measure of the hormonal function of the placenta, should add considerably to our understanding of the physiology of the onset of labour.

There remains the question of whether amniocentesis is safe-especially with a dead foetus. We know of no maternal deaths resulting directly from the use of saline in the many large series of legalized abortions from Scandinavia. However, a raised temperature after these inductions gives great copcern, and since we followed the suggestion of Brosset (1958), that a single dose of oxytetracycline should be introduced into the uterus after the saline, we have had no pyrexial cases.

Finally, it is of interest to note that five of our patients have conceived again after their saline inductions, and four of these have already had normal deliveries at term.

\section{Summary}

In 32 patients labour or abortion has been successfully induced with the intra-amniotic injection of hypertonic (20normal) saline.
The indications were therapeutic abortion, intrauterine death of the foetus, and gross foetal abnormality.

In five cases increased uterine sensitivity to an oxytocin infusion was demonstrated.

Labour was usually rapid and efficient.

The technique provides a means of emptying the uterus safely at any period of gestation.

Further study is necessary before the optimum dose for cases with hydramnios can be determined.

We wish to express our thanks to Mr. S. Davidson, Miss D. M. Shotton, Mr. A. L. Deacon, Mr. W. G. Mills, Mr. H. Roberts, and Mr. G. E. E. Usher-Somers for their constant interest, advice, and encouragement in the preparation of this paper. The patients were treated at the Birmingham Maternity Hospital, the Birmingham and Midland Hospital for Women, and Hallam Hospital, West Bromwich.

\section{REFERENCES}

Abdul-Karim, R., and Assali, N. S. (1961). 7. Lab. clin. Med., 57, 522. Aburel, E. (1934). Communicare la Sociecatea Stiintelor Medicale, Iasi. Barry, A. P., Geobegan, F., and Shea, S. M. (1955). Brit. med. f., 2, 287.

Bengtsson, L. P. (1961a). In Brook Lodge Symposium Progesterone, edited by A. C. Barnes, p. 49. Brook Lodge Press, Augusta, Michigan.

(1961b). In Ciba Symposium No. 9, Progesterone and the Defence Mechanism of Pregnancy, edited by G. E. W. Wolstenholme and M. P. Cameron. Churchill, London.

(1962). Lancet, 1, 339.

- and Csapo, A. I. (1962). Amer. 7. Obstet. Gynec., 83, 1083.

Briggs, D. W. (1964). Brit. med. F., 1, 701.

Brosset, A. (1958). Acta obstet. gynec. scand., 37, 519.

Burke, F. J. (1935). 7. Obstet. Gynaec. Brit. Emp., 42, 1096.

Corbett, H. V. (1958). Ibid., 65, 100.

Csapo, A. I. (1955). In Modern Trends in Obstetrics and Gynaecology, 2nd series, edited by K. Bowes, p. 20. Butterworth, London. - (1961a). In Oxytocin, edited by R. Caldeyro-Barcia and H. Heller. Pergamon Press, Oxford.

- (1961b). In Ciba Symposium No. 9, Progesterone and the Defence Mechanism of Pregnancy, edited by G. E. W. Wolstenholme and M. P. Cameron, p. 3. Churchill, London.

(1961c). In Brook Lodge Symposium Progesterone, edited by A. C. Barnes, p. 7. Brook Lodge Press, Augusta, Michigan.

(1961d). Lancet, 2, 277.

(1963). Amer. 7. Obstet. Gynec., 85, 359.

Jaffin, H., Kerenyi, T., Lipman, J. I., and Wood, C. (1963a). Ibid., $85,819$.

Ibid., 87, 892 .

and Lloyd-Jacob, M. A. (1962). Ibid., 83, 1073.

Cunningham, I. (1965). Lancet. In press.

Dunlop, J. C. H. (1964). Simpson Memorial Maternity Pavilion Report for 1963, p. 98.

Harvey, L. P. (1964). Brit. med. f., 1, 1256.

Hendricks, C. H., Brenner, W. E., Gabel, R. A., and Kerenyi, T. (1961). In Brook Lodge Symposium Progesterone, edited by A. C. Barnes, p. 53. Brook Lodge Press, Augusta, Michigan.

Liggins, G. C. (1962). 7. Obstet. Gynaec. Brit. Cwlth, 69, 277.

Loudon, J. D. O. (1959). Ibid., 66, 277.

MacDonald, D., O'Driscoll, M. K., and Geohegan, F. J. (1965). Ibid., 72, 452 .

Martin, R. H., and Menzies, D. N. (1955). Ibid., 62, 256.

Mayes, B. T., and Shearman, R. P. (1956). Ibid., 63, 812.

Playfair, P. L. (1941). Ibid., 48, 41.

Quinn, L. J., and Harper, J. A. (1955). Ibid., 62, 280.

Reinberger, J. R., and Mackey, W. F. (1958). Amer. F. Obstet. Gynec., 76, 288 .

Russell, C. S. (1961). In Ciba Foundation No. 9, Progesterone and the Defence Mechanism of Pregnancy, edited by G. E. W. Wolstenholme and M. P. Cameron. Churchill, London.

Short, R. V., Wagner, G., Fuchs, A. R., and Fuchs, F. (1965). Amer. F. Obstet. Gynec., 91, 132.

Svane, H. (1960). Dan. med. Bull., 7, 51.

Wagner, G., Karker, H., Fuchs, F., and Bengtsson, L. P. (1962). Ibid., 9, 137.

Wiqvist, N. E., and Eriksson, G. (1964). Amer. 7. Obstet. Gynec., 88, 75 .

Wood, C., Booth, R. T., and Pinkerton, J. H. M. (1962). Brit. med. f., 2, 706 .

Zander, J. (1961). In Brook Lodge Symposium, Progesterone, edited by A. C. Barnes, p. 77. Brook Lodge Press, Augusta, Michigan. 